practice. The pursuit by a doctor of a research or teaching interest is not inimical to a service commitment.

The primary teaching responsibility of the departments is for the undergraduate phase, since much of the work of vocational and continuing education is undertaken more frequently, and perhaps more appropriately, outside the departments. The contribution of a lecturer to the teaching, service, and research work of a department will vary with his experience. Even if he has only completed a general practice vocational training he will already be four years post-graduation. His four years will have been wasted if at this stage he has nothing to teach the undergraduate about diagnosis in general practice, continuity of care, the doctor-patient relationship, the social effects of disease, etc.

Any academic department has a responsibility for the in-service education and training of its members. The Royal College of General Practitioners has suggested that the fifth postgraduate year of training for general practice might be appropriately spent in further study of the behavioural sciences, epidemiology, sociology, or medical statistics in the context of general practice. ${ }^{34}$ At the present time posts which even approximate to this concept of "senior registrar in general practice" are only to be found in departments of general practice. A lecturer in general practice may therefore have only limited general practice experience at the time of his appointment. I am, etc.,

Edinburgh

PhILIP L. Heywood

1 McWhinney, I R., Lancet, 1956, 1, 419 .

2 Forrest, A. P. M., Scottish Medical fournal, 1971, $16,463$.

3 Royal College of General Practitioners, Reports from General Practice, No. 1. London, R.C.G.P., 1965. Royal College of General Practitioners, Reports
from General Practice, No. 6. London, R.C.G.P.,
1967.

\section{Ambulance Noise}

SIR,-May I, as accident medical officer to Bath Fire Brigade and Ambulance Service, be permitted to reply on behalf of the emergency services to Dr. J. H. Henderson's letter on ambulance noise (11 March, p. 694).

When attending an accident, emergency, or fire the driver of an emergency vehicle has two alternatives: to progress as an unidentified vehicle in the ordinary traffic flow and wait in queues, or to avoid undue delay and maintain a course that takes his vehicle safely through traffic at a speed slightiy faster than that of the prevailing traffic flow. To answer an emergency call, seldom knowing any detail of the incident except the location, surely involves the second alternative, and to this end the Home Office lays down attendance times for fire appliances to reach an incident in a given fire risk category.

In conjunction with the Fire and Ambulance Service I have just completed a university research project on the provision of medical aid at the scene of accidents. One of the findings was that the time taken by the emergency services to arrive at the scene was very important with regard to the survival of the seriously injured. Similarly, early arrival prevented the mishandling of patients by persons untrained in first aid who, though well intentioned, were seen to have worsened the patients' injuries on at least two occasions. Because of the more immediate effect of an audible warning as compared with visual identification the former can be essential under certain traffic conditions both for reasons of safety and prevention of unnecessary delay.

In my experience of working closely with all three emergency services in the last nine years I recognize the degree of responsibility with which these vehicles are driven, and how infrequently they are involved in accidents. Any drama attached to such occasions is related more to portrayal on films and television than in real life. The noise of an alternating emergency horn is not unpleasant, and is of short duration in passing any one person, and surely represents an insignificant disturbance in relation to the benefit to those involved in the emergency. It has for instance been reported in the press that people trapped by fire have delayed jumping from high buildings on hearing the approach of the emergency vehicles. (Leinster Towers Hotel fire, London, 6 June 1969.)

The class of emergency and speed with which a doctor can be found to attend an incident does not always correspond with that of the emergency services, though where doctors have formed groups to attend accidents they are already using the B.M.A. green flashing light.-I am, etc.,

Dunkerton, Bath

R. SNOOK

\section{Legislative Power}

SIR,-I have read very carefully the report by the Central Committee for Hospital Medical Services (Supplement, 4 March, p. 56). In the latter part of the eighteenth century the historian Edward Gibbon wrote (I quote from memory), "The principles of a free constitution are irrecoverably lost when the legislative power is ncminated by the executive." I suggest, $\mathrm{Sir}$, that the issue under discussion by the Central Com-

mittee is exactly that to which Gibbon refers, and that, if the statement was true when Gibbon wrote it, it is equally true today. No sophistry can assail it.-I am, etc.

Gibraltar

T. KNOWLES BONEY

\section{Doctors and Overpopulation}

SIR,-Mr. H. G. E. Arthure's letter (26 February, p. 566) only emphasizes the point that we made (5 February, p. 377) on the struggle there has been to get contraceptive instruction to midwives. He states, as we are well aware, that this was introduced by the Central Midwives Board in 1968. It is a good thing some of us were teaching midwives on the subject of family planning before this date. Never mind the question of overpopulation; it has been one of the axioms of obstetrics that mothers should have at least two-year gaps between the births of their babies, but how little advice has been given over the years to enable them to achieve this.

In the third paragraph of his letter, Mr. Arthure states "that the Board does not include the practical application of contraceptive methods in its syllabus but encourages midwives to attend Family Planning Association courses." We agree that this is a move in the right direction, but it does leave this essential training of midwives as an optional part of their course

We appreciate that advice on techniques of contraception and sterilization is essentially the province of the doctor, but as the community nursing staff becomes more closely attached to family doctors and hospitals they should be playing their full part in assisting parents to plan their children. -We are, etc.,

SHIRLEY NICHOLAS P. NICHOLAS

Wirral, Cheshire

\section{Impartiality of "B.M.J."}

SIR,-Your Apology (4 March, p. 633) is of the greatest importance for it has brought to light an episode which calls into question the impartiality of the British Medical fournal in medicopolitical affairs. To understand the implications your readers should know the whole story.

On 1 January 1972, the B.M.F. reported (Supplement, p. 1) that the Central Committee for Hospital Medical Services, at its meeting on 16 December 1971, had decided to oppose the application of the Regional Hospitals Consultants and Specialists Association for representation on the Joint Consultants Committee. Mr. S. C. Simmons spoke against the decision in the debate. On 7 January I submitted for publication in the Journal a letter attacking the decision, but when I examined a proof which was sent to me on 17 January I saw that my letter had been altered, and as the Editor was not prepared to publish it in its original form I withdrew it. Twelve days later a letter from Dr. C. E. Astley, Chairman of the C.C.H.M.S., appeared in the Journal (29 January, p. 315). It purported to be an answer to statements made by Mr. S. C. Simmons in the C.C.H.M.S. debate, but a cursory examination revealed that they were statements Mr. S. C. Simmons had not made. Tine truth of the matter was that without my knowledge my unpublished letter had been shown to the C.C.H.M.S. Chairman, Dr. Astley, who had thus been given an opportunity of commenting upon it before its scheduled publication. It was in answer to my letter that Dr. Astley had written. Mr. S. C. Simmons, who had been wrongly accused of having said something he had not, was indignant and wrote a letter to the Journal which refuted Dr. Astley's allegations and answered points Dr. Astley had raised. This letter has yet to be published; instead, on 4 March, your Apology appeared.

The episode has demonstrated that chairmen of B.M.A. committees may be shown letters sent to the Journal before publication and without the author's knowledge. Why was Dr. Astley shown my letter? One memthat all letters on medicopolitical subjects are shown to the Secretariat so that "errors of fact can be corrected by a footnote," but Dr. Astley is not a member of the Secretariat. I accept that the Journal will be more readable if questions put by correspondents ber of the Journal's editorial staff told me 